\title{
Writing the History of Aristotelian Logic During the Long Ninth Century
}

\section{Christophe Erismann*}

\section{Description of the Project}

The project Reassessing Ninth Century Philosophy. A Synchronic Approach to the Logical Traditions (9 SALT), ${ }^{1}$ funded for five years (2016-2020) by the European Research Council (ERC consolidator grant 648298) and hosted by the Institute for Byzantine and Modern Greek Studies of the University of Vienna, aims at a better understanding of the philosophical richness of ninth century thought using the unprecedented method of a synchronic approach. The hypothesis guiding this synchronic approach is that studying together in parallel the four main philosophical traditions of the century - i.e. Latin, Greek, Syriac and Arabic will bring results that the traditional enquiries limited to one tradition alone can never reach. The ninth century, a time of cultural renewal in the Carolingian, Byzantine and Abbasid empires, possesses the remarkable characteristic that the same texts, namely the writings of Aristotelian logic (including also Porphyry's Isagoge), were read and commented upon in Latin, Greek, Syriac and Arabic alike.

The project studies, in a precise historical context, fundamental questions related to the human capacity to rationalise, analyse and describe sensible reality; to understand the ontological structure of the world; and to define the types of entities which exist. It provides a unique opportunity to compare different traditions and to highlight their common Aristotelian heritage, to stress the specificities of each tradition when tackling philosophical issues and to discover the doctrinal results triggered by their mutual interactions, be they constructive (scholarly exchanges) or polemic (religious controversies).

Logic is fundamental to philosophical enquiry, but it is also a a powerful tool when used outside a strictly philosophical context. Logic is an extremely useful way to strengthen one's own position, by establishing conclusions through rational deductions and by proposing syllogistic reasoning, and also to undermine the position of an adversary in an intellectual or religious controversy, by showing that his opinion implies contradictions or absurd consequences. Studying occurrences of such uses of logical tools is, for the historian, a precious means to assess the place of rationality in public discourses.

* Correspondence details: Christophe Erismann, University of Vienna, Institute for Byzantine and Modern Greek Studies, Postgasse 7/1/3, 1010 Vienna, Austria. Email: christophe.erismann@univie.ac.at. For more details, please refer to the project website: www.univie.ac.at/9salt.

1 The principal investigator and project leader is Christophe Erismann. The following researchers have worked or are working for the project: Byron MacDougall, Adam McCollum, Philippe Vallat, Caterina Tarlazzi, Dirk Krausmüller and Benedetta Contin. Elvira Wakelnig and Jocelyn Groisard are associated researchers. The advisory board of the project is constituted by Claudia Rapp (Vienna), John Duffy (Harvard), John Marenbon (Cambridge), and Henri Hugonnard-Roche (Paris). 
The history of logic in the ninth century consists mainly of the study of the reception and use of Aristotle's six logical writings (The Categories, On interpretation, the Prior and Posterior Analytics, the Topics and the Sophistical Refutations), also known collectively as the Organon, together with the introduction to the Categories (the Isagoge) written by the third-century philosopher, Porphyry. The first half of the project has been devoted to a careful reading and analysis of the logical texts written during the ninth century - here I use the term »logical texts « in the broad sense of »texts related to logic «; they may be exegetical works on Aristotelian treatises or any kind of discussion of their contents -, to a study of manuscripts containing either a part or the totality of the Organon, or commentaries on one of these texts by late ancient philosophers (such as Porphyry, Simplicius, Ammonius or Elias) copied during the long ninth century (including the study of glosses in the case of glossed manuscripts), and to an analysis of ninth-century texts using Aristotelian logic although their primary concern is not philosophical (this includes, for example, the numerous polemical theological treatises that use logical tools). This has led to reflections on what methods should be followed and on the nature of the object that is to be studied. In this short contribution, I would like to propose my (present) views about these two questions.

\section{What constitutes the reception of an ancient text?}

This project deals with an historical phenomenon, i.e. the reception of ancient and late ancient logical texts in various cultural milieus, during a precise time-frame: the long ninth century (a period which could respectively be characterized as early medieval in the West, as a part of the middle Byzantine period or as classical for the Arabic tradition). My guidelines and convictions are that we should adopt a far broader concept of reception in order to understand the real impact of a philosophical text on a given society than the one tacitly used in previous scholarship. The traditional approach in the history of philosophy to the reception of a text in a late ancient or medieval period is to list and study the commentaries written on that work; this is grounded in the assumption that commentaries are the main place of interactions with an ancient text. In the case of the ninth century, such a limited approach would give only a very partial view and lead to the conclusion that Aristotelian logic was of some interest but not central at the time, as we only have a very small number of exegetical works. To take an example: in the Byzantine tradition we can hardly mention more than a dozen Amphilochia on logic by Photius and a set of glosses by Arethas which are almost exclusively excerpts from late ancient commentaries by the Alexandrian Neoplatonists. A more inclusive approach gives a far richer and more correct representation. I claim that, to the study of commentaries, we should add three other categories which have to be considered. In order to offer a comprehensive representation of the reception of an ancient (Aristotle) or late ancient (Porphyry) logical text during the ninth century, four components have to be analysed:

First, it should include the study of the transmission of the logical texts themselves (in the case of Byzantium, the original Greek text; for the other traditions, its translation into Latin, Syriac or Arabic, the existence of which is indeed the first clear sign of interest in that text). The decision to have a work copied, given the expenses involved (including writing material and scribal labour), is itself not without significance; it is the proof of a positive assessment of the usefulness and importance of this given text. When a scribe, a scriptorium, a commissioner or a possessor can be identified, this information is very useful for obtaining a more precise depiction of the audience of logical texts: is the manuscript related to a monastic community, to a school or to a well-known scholar, for example Arethas of Caesarea and the Biblioteca Apostolica Vaticana, Urb. Gr. 35 in Byzantium or Leidrad and the Biblioteca Apostolica Vaticana, Pagès 1 in the Latin West? 
In the same vein, it is interesting to study the other texts copied in the same codex (as long as the unity of the codex is proved paleographically and codicologically). Is the codex constituted by several Aristotelian treatises, the entire Organon, together with Porphyry's Isagoge? Or does it consists of a single logical text accompanied by a late ancient commentary? Or is the logical content mixed with theological writings? This last scenario indeed occurs more frequently in the case of logical compendia written for theologians. An interesting example of the phenomenon is a palimpsest manuscript in Athens, the Greek National Library 182 which contains in scriptura inferior (of the ninth century according to D. Harlfinger) John of Damascus's Dialectica together with commentaries on the Isagoge by Ammonius and on the Categories by Ammonius and Elias. ${ }^{2}$ This gives information about the purpose of the study of logical texts: logic could be studied for itself in a philosophical approach ${ }^{3}$, as a toolbox for theology or religious controversies, or combined with rhetoric ${ }^{4}$ as a way to argue convincingly for one's own position.

The second component which should be incorporated into the inclusive approach to reception is the study of the textual vectors of the indirect transmission of the logical texts. This corresponds to a mode of reception which combines absorption and rewriting activity; it concerns abridged and simplified versions of the original treatise (compendia, handbooks), rewritten versions (paraphrases) or excerpts transmitted in lists of definitions of logical terms. These writings are part of the reception for at least two reasons: because they attest to a positive evaluation of the utility of the matter covered by the original text and because they often play a key role in the diffusion of the content of the logical writing in question. The $D i$ alectica of John of Damascus constitutes the ultimate example of this literary genre. A proper analysis of the reception of Aristotle's Categories (the text) and categories (the doctrine) in ninth-century Constantinople should include not only a study of the reception of the text of the Categories itself, but also of the logical compendia (in the abridged version of the textual samples edited by Mossman Roueché ${ }^{5}$ or in the more extended version of the Dialectica) and of the late ancient commentators (Porphyry, Ammonius, Simplicius, Elias, etc.).

The third component to be studied is the set of testimonies for the use of the text. The most obvious manifestation of this are quotations which explicitly mention the name of the author, such as "Aristotle says that ...", which are often quotes from memory (as such they are not necessarily citing the text exactly, but are a source of what was memorised); but often the use of logical text is anonymous and not openly endorsed (the origin of such a practice is related to the fact that Aristotle was a Pagan who defended doctrines antithetical to Christian views, and Porphyry a notorious anti-Christian writer). This does not mean that silent quoting or use of given concepts could not be traced back. In the case, for example, of the use by Byzantine iconophile theologians of the Aristotelian doctrines of the homonyms on the one hand codices containing only logical texts are manuscripts in Milan, Biblioteca Ambrosiana, L o93 sup. of the end of the ninth century, in Rome, Biblioteca Apostolica Vaticana, Urb. Gr. 35 and in Venice, Biblioteca Nazionale Marciana gr. Z. 201 of the mid-tenth century. 
and of the relatives ( $t a$ pros $t i$ ) on the other, it is possible to identify both silent quotes and the use of determinate concepts. An interesting case is, for example, Arethas, who chose to refer to Aristotle not by his name, but through his origin (»the Stagirite"), which makes the source of the reference to the Aristotelian doctrine of homonyms clear to the informed

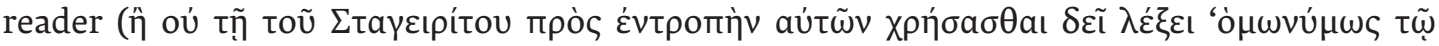

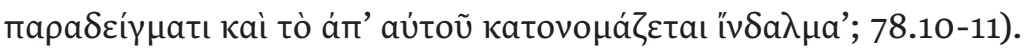

The fourth, and more traditional, component is the inventory and analysis of the commentaries written on the text. Exegetical activity, which often reflects a previous teaching activity, is the most visible part of the polymorphous phenomenon of the reception of an ancient text. This exegetical activity could take the form of marginal glosses, (lemmatic) commentaries or short treatises discussing the text. The function of glosses and of commentaries is not the same. Glosses are present as a possible help to the reader or an additional development, like a quote from a late ancient commentator, which one can read or not. A commentary, however, is read in continuo. The presence of diagrams and their functions also has to be analysed.

The third point listed leads me to my second remark.

\section{What counts as a logical text?}

One major result of the project so far, which has consequences for the way in which the history of Aristotelian logic during the ninth century has to be written, is a reassessment of the nature of texts which have to be considered in the history of logic. A standard approach to the logical tradition (which one finds in histories of logic if they take time to consider the early Middle Ages, the Byzantine tradition or the Syriac texts, which are often neglected) does study the commentaries, glosses and all forms of exegetical texts on Porphyry's Isagoge and Aristotle's Organon. Such an approach is unable to give a proper account of the actual study and knowledge of logic during the century. It has now become apparent that one fascinating and central object of study consists of texts not on logic, but texts with logic. We would call this nowadays "applied logic", by which I mean the use of the practical art of correct reasoning, of proving a position, of showing the absurd consequences of the adversary's opinion, of deductive and inductive reasoning and of using terms and concepts from Aristotelian logic, such as concepts from the Categories, to elaborate one's own views on a question.

These texts which apply logic are extremely rich mines of information. They are more personal than exegetical works, as they are directly connected to the intellectual debates of the time, since logic is used to defend a position. They are also more original, as it is not a matter of reproducing traditional opinions, but of creating new arguments. Being more personal and original, they show better what the logical culture of their author has been than a reproduction of a well-codified exegesis.

If some elements of applied logic have been previously identified (though generally without proper study), none realised the extent, the importance and the richness of this phenomenon. To take just one example in the Byzantine tradition: logic is present in all the major theological debates of the century (the use of logic in theology is not an innovation of the ninth century as such and was already present in late patristic Christological disputes, but ninth-century authors applied logic consistently and to debates which were previously not addressed in a logical way). It starts with the major intellectual, political and theological debate of the time: iconoclasm. The massive introduction of logical concepts in reasoning in iconophile writers is the turning point of the controversy. This new theological methodology - for we can really use such a bold term for this new form of rational theology (the only prec- 
edent, but with several differences, would be the late patristic Christological disputes) - will be further developed by Photius in his Mystagogy ${ }^{6}$ and by Niketas of Byzantium, a polemicist active in the second half of the ninth century, in his treatises against Islam. The latter claims that he bases his refutation of Islam on common concepts and natural (i.e. logical and rational) arguments and that he does not defend Christianity using the Scriptures.

The importance of applied logic can be observed in all the four traditions studied by 9SALT. For the Latin tradition, it is present in texts like Ratramnus of Corbie's De anima but also in the Libri Carolini, in which logic is used by the Franks as a way to establish their literacy. For the Syriac tradition, examples are numerous, but a striking example is the correspondence between Leo of Harran and Eliya. Numerous polemical treatises in Arabic (notably by Theodore Abu Qurrah and Ammar al-Basri) attest to the same.

\section{Accomplished work}

The first three years of the ERC project 9SALT have been very intense, fruitful and productive. The greatest satisfaction is the confirmation of the philosophical richness and the variety of texts under scrutiny, i.e. Greek, Syriac, Latin and Arabic ninth-century logical texts or writings dealing with Aristotelian logic. After a long process of translation and a doctrinal analysis, it is clear that this material has a lot to offer both in itself ${ }^{7}$ and in a comparative reading, confirming the relevance of the synchronic approach.

The team has carefully considered manuscripts containing logical texts in the various traditions, copied during the ninth and early tenth centuries in the Carolingian Kingdom, in Byzantium and in the Syriac-speaking communities (the preserved Arabic manuscripts of logical texts are chronologically posterior). This is fundamental to understanding how logic was read, studied and transmitted. Only an inclusive approach summarizing the information in the way in which texts were transmitted gives us the opportunity to describe trends in the modalities of transmission (for example, whether the texts were copied by excerpts or in their entirety, alone or with other texts, whether the text is the original version or a paraphrase and, more specifically, whether the entire Organon was copied or only some texts and if so, whether the combination of texts is always the same). A reader faced with an entire copy of the Organon and one facing a summary of the Categories will not have the same impression of what logic is. It is significant to know the size of the manuscript, if it is a composite manuscript gathering logical texts with others writings, if there are glosses or diagrams in the margins. Forthcoming results of this enquiry include a careful study by Adam McCollum of the Syriac manuscript Vatican Sir. 158 (a remarkable collection of logical texts in Syriac), an exhaustive study of the early medieval Latin transmission of Porphyry's Isagoge by Caterina Tarlazzi, and a study of several Byzantine manuscripts including logical texts or texts using logic from the end of the ninth century. For Byzantium, this allows us to document the very interesting practice of excerpting arguments, which has, until now, never been studied.

6 As for Photius's use of logic in his Mystagogy, see Erismann, Theological Dispute, Logical Arguments.

7 See, for example, Erismann, Photius and Theodore the Studite on the Humanity of Christ. A neglected Byzantine discussion on universals; ibid. Meletius Monachus on individuality; ibid. Ontologie et logique; ibid. Venerating Likeness; ibid. On the Significance of the Manuscript Parisinus graecus 437. 
An interesting case is constituted by a section of the Antirrhetici (i.e. Nicephorus's doctrinal answer to iconoclast ideology as theorized by Constantine V), in which Nicephorus gives ten arguments, in a syllogistic form, to show the superiority of the image of Christ over the representation of the Cross. These ten arguments were first integrated in a tenth-century manuscript - a remarkable codex containing treatises by Maximus the Confessor, Theodore of Raithu, John of Damascus and Theodore Abu Qurrah - the Milan, Biblioteca Ambrosiana Q 074 sup., folio $247 \mathrm{v}$ to $250 \mathrm{v}$. The ten syllogisms were then to appear in at least six manuscripts, often entitled On the Difference between the Image of Christ and the Cross, between the eleventh and the twelfth century (Moscow, Sinod. Gr. 467 - Venice, Biblioteca Nazionale Marciana gr. III.017 - London Lambeth Palace Library, Sion L40.2 Go6 - Roma, Biblioteca Vallicelliana, Allacci 38, and the Vaticanus Graecus 2198), followed by at least eight more recent copies. It seems likely that the reason for the success of Nicephorus's ten syllogisms about the image of Christ and the Cross is related to the method of which they are an illustration. They can be taken as teaching examples of a rational and logical defence of a theological position, and a masterful application of Aristotelian logic to the theological discourse. ${ }^{8}$

As planned, a significant part of the first years of the project has been devoted to the selection, translation and analysis of suitable texts. A point which applies to all the traditions studied may be mentioned first: translation is always the first step in philosophical analysis. Before being able to reconstruct and analyse arguments, a careful translation, which respects the specific characteristics of the conceptual vocabulary used, is needed. For this reason, considerable effort was devoted to creating a set of working translations of key texts. A selection of these translations will be published in an anthology of logical texts and will, without doubt, constitute an important and useful result of the project (the publication is foreseen in the series Liverpool Translated Texts for Historians). The book project is entitled After Alexandria: Syriac, Byzantine and Arabic Christian Logical Treatises from the Sixth to the Ninth Century and will offer an extensive selection of short logical treatises, handbooks or compendia - ranging from two to forty pages in length - and of self-contained sections of longer texts, which have often also been transmitted independently in the manuscript tradition, written between the sixth and the ninth century. These texts, written by Christian authors in Greek, Syriac and Arabic, offer an in-depth perspective on a phenomenon characteristic of the eastern Mediterranean world throughout this period: a sustained interest in the teaching and study of logic. The treatises vary in nature and include teaching materials, compendia covering one aspect of logic or offering a summary of several books of Aristotle's Organon, logical sections of theological texts, collections of definitions and short treatises focusing on one specific question. ${ }^{9}$ The chronology adopted for the choice of texts to be translated was

9 The volume will contain: Paul the Persian, Logic (Syriac) - Sergius of Reshaina, On genus, species and individuality (Syriac) - Heraclianus of Chalcedon, all the surviving fragments (= § 42-43 of the Doctrina Patrum, Greek) - Leontius of Byzantium, Contra Nestorianos et Eutychianos (Greek, first section) - Pamphilus, Chapters (Greek, nos. 1 and 2) - Theodore of Raithu, Proparaskeue (Greek, the second section) - Leontius of Jerusalem, Contra Nestorianos (Greek, selected excerpts) - Maximus the Confessor, Letter XV, On common and proper, that is essence and hypostasis (Greek) - »Maximus the Confessor", Opuscula theologica et polemica XIV and XXIII (Greek) - Anastasius Apocrisiarius, Epistula ad monachos Ascalonitas (Greek, first part) - Anastasius Sinaiticus, Hodegos (Greek, section on definitions) - Jacob of Edessa, Encheiridion (Syriac) - Anonymous (ed. Roueché), Logical compendia (Greek) John of Damascus, Institutio elementaris (Greek) - Pseudo-Athanasius, Sermon on annunciation (Greek, first part) - Theodore Abu Qurrah, Distinction and clarification of the terms used by philosophers (Greek), Photius, Amphilochia 138 On Substance (Greek) - Ibn Bahriz, On the definitions of logic (Arabic). 
voluntarily wide, going back to the sixth century. The main argument for this choice is that if one wants to understand properly the specific characteristics of the ninth century, one needs to have a proper representation of the situation in the centuries before. The changes occurring during the ninth century will only become clear if one knows what the situation was like before.

As the results of research have to be diffused and are enriched by critical discussion, three international conferences ${ }^{10}$ have been organised in Vienna with the participation of distinguished scholars from various fields:

- »Theodore the Stoudite. Intellectual Context, Logic, and Theological Significance« (University of Vienna, 9-11 March 2016)

- »Understanding Individuality and Depicting Individuals in Ninth Century Byzantium« (University of Vienna, 1-3 March 2017)

- »Arguing Against. Logical Reasoning and Arguments in Religious Controversies (8th -10th Centuries)«, (University of Vienna, 28 February-2 March 2018).

\section{Expected results}

Numerous results are expected by the end of the project in 2020. They are of three kinds.

First, a new narrative of the history of logic during the ninth century. The traditional description includes only the analysis of the exegetical work done during the ninth century on Aristotelian logical texts. 9SALT takes into consideration a lot more material, by including in its study writings which are not primarily philosophical but in which logic is abundantly used. The consideration of this material allows a more detailed and precise picture, and a better evaluation of the role of logic, the level of scholarship and the logical culture of the main thinkers of the century. This aim will be fulfilled through research articles and a monograph by the principal investigator.

Secondly, the use of the unprecedented synchronic approach will facilitate a deeper understanding of the positions held at the time, a clear identification of the a priori postulates (proper to each tradition) of the philosophical debates, and a critical evaluation of the arguments used. This will be done through a comparison of the way in which philosophical problems are answered in the different traditions.

Third, the new attention devoted to texts that have never before been translated in English or any other modern language, in some cases including editions of the text in the original language. This will notably be accomplished by the previously mentioned anthology of logical texts in translation. ${ }^{11}$

10 For the programme of these conferences and a list of the talks given by the principal investigator and the project members, see www.univie.ac.at/9salt/index.php?seite=events.

11 I would like to express my gratitude to Christian Gastgeber for his helpful comments on this report and to thank Ingrid Hartl for her remarks. 


\section{References}

\section{Manuscripts}

Athens, Greek National Library, 192

London, Lambeth Palace Library, Sion L40.2 Go6

Milan, Biblioteca Ambrosiana Q 074 sup.

Moscow, Historical Museum, Sinod. Gr. 467

Roma, Biblioteca Vallicelliana, Allacci 38

Vatican, Biblioteca Apostolica Vaticana, Gr. 2198

Vatican, Biblioteca Apostolica Vaticana, Pagès 1

Vatican, Biblioteca Apostolica Vaticana, Sir. 158

Vatican, Biblioteca Apostolica Vaticana, Urb. Gr. 35

Venice, Biblioteca Nazionale Marciana gr. III.017

\section{Secondary Literature}

Erismann, Christophe, Theological Dispute, Logical Arguments: On Photios' use of syllogisms against the Filioque in the Mystagogia, in: Alessandra Bucossi et Anna Calia (eds.), Contra Latinos et Adversus Graecos: The separation between Rome and Constantinople from the 9 th to the 15th century (Louvain, forthcoming).

Erismann, Christophe, Nicephorus I of Constantinople, Aristotelian Logic and the Cross, in: Mikonia Knežević (ed.), Aristotle in Byzantium (Alhambra, CA, forthcoming).

Erismann, Christophe, Photius and Theodore the Studite on the Humanity of Christ. A neglected Byzantine discussion on universals, Dumbarton Oaks Papers 71 (2017) 175-192.

Erismann, Christophe, Meletius Monachus on individuality: a ninth-century Byzantine medical reading of Porphyry's Logic, Byzantinische Zeitschrift 110/1 (2017) 37-60.

Erismann, Christophe, Ontologie et logique à Byzance. Photius Ier de Constantinople et la distinction entre les termes shommer et shumanitér, in: Les Études Philosophiques 177 (2018.3) 363-376

Erismann, Christophe, Venerating Likeness: Byzantine Iconophile Thinkers on Aristotelian Relatives and their Simultaneity, British Journal for the History of Philosophy 24/3 (2016) 405-425.

Erismann, Christophe, On the Significance of the Manuscript Parisinus graecus 437. The Corpus Dionysiacum, Iconoclasm, and Byzantine-Carolingian Relations, in: Falco Daim, Christian Gastgeber, Dominik Heher, Claudia Rapp (eds.), Menschen, Bilder, Sprache, Dinge. Wege der Kommunikation zwischen Byzanz und dem Westen (Mainz, 2018) 95-101.

MacDougall, Byron, John of Sardis' Commentary on Aphthonius' Progymnasmata: Logic in Ninth-Century Byzantium, Greek, Roman, and Byzantine Studies 57 (2017) 721-744.

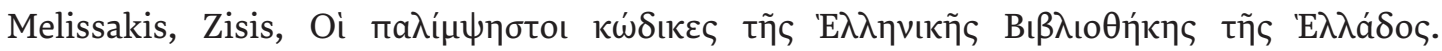

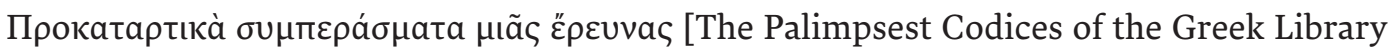
of Greece. Preliminary Conclusions of a Survey], Symmeikta 16 (2003) 159-216. dx.doi. org/10.12681/byzsym.910.

Roueché, Mossman, Byzantine Philosophical Texts of the Seventh Century, JÖB 23 (1974) 61-76. 